\title{
Comparison of Microscale sealed vessel pyrolysis (MSSVpy) and hydropyrolysis (Hypy) for the characterisation of extant and sedimentary organic matter
}

Lyndon J. Berwick ${ }^{\mathrm{a}}$, Paul F. Greenwood ${ }^{\mathrm{a}, \mathrm{b}} *$, Will Meredith ${ }^{\mathrm{c}}$, Colin E. Snape $^{\mathrm{c}}$ and Helen M. Talbot ${ }^{\mathrm{d}}$

\footnotetext{
${ }^{a}$ WA - Organic and Isotope Geochemistry Centre, Department of Applied Chemistry, Curtin University, GPO Box U1987, Perth, WA 6845.

b John de Laeter Mass Spectrometry and WA Biogeochemistry Centres, University of WA, Stirling Hwy, Crawley, 6009; Australia

${ }^{\mathbf{c}}$ University of Nottingham, Department of Chemical \& Environmental Engineering, Faculty of Engineering, University Park, Nottingham NG7 2RD, UK.

${ }^{\mathrm{d}}$ School of Civil Engineering and Geosciences, Newcastle University, Newcastle upon Tyne, NE1 7RU, UK.

*Correspondence: paul.greenwood@uwa.edu.au
}

Keywords: Microscale Sealed Vessel, MSSV, hydropyrolysis, Hypy, analytical, pyrolysis, organic, biomarkers, hopanes, asphaltenes, thiophenes. 


\begin{abstract}
MicroScale Sealed Vessel Pyrolysis (MSSVpy) and catalytic hydropyrolysis (Hypy) combined with gas chromatography mass spectrometry have emerged in recent years as useful and versatile organic analytical and characterisation methods. Both now commercially available, these pyrolysis methods complement traditional flash pyrolysis analysis which can be limited by excessive degradation or inadequate chromatographic resolution of pyrolysates of high structural polarity. To assess the versatility and merits of these two pyrolysis methods they were separately applied to several organic samples reflecting different thermal maturity. This comparison revealed many product similarities, but also several important features unique to each. Both produced $\mathrm{C}_{27}-\mathrm{C}_{33}$ hopane products from a bacterial isolate and a membrane biofoulant from a water filtration system. Increased concentrations of higher MW and $\beta \beta$-stereoisomeric hopanes detected by Hypy reflect more selective bond cleavage, attributed to a relatively short residence time and catalyst assisted reduction of volatilisation temperatures, of the mostly $\mathrm{C}_{35}$ $(\beta \beta-)$ bacteriohopanepolyol precursors established by corresponding LCMS analysis. When applied to the asphaltene fraction of a biodegraded oil both pyrolysis methods were able to regenerate similar distributions of liquid $n$-alkanes and source diagnostic hopane and sterane biomarkers removed from the free phase of oil by the biodegradation. The detection of low MW $\left(<\mathrm{C}_{8}\right)$ products was only supported with the online GCMS analysis of the MSSVpy procedure. This advantage was again evident in the MSSVpy detection of low MW alkyl $\left(<\mathrm{C}_{2}\right)$ thiophenes from the S-rich Kimmeridge clay. Similar distributions of higher MW alkyl benzothiophenes and alkyl dibenzothiophenes were detected directly by MSSVpy, and after derivatisation of the polar fraction of the Hypy extract, consistent with the sensitive detection of other heteroatom bound structural units previously demonstrated by both methods.
\end{abstract}




\section{Introduction}

Analytical pyrolysis is a useful procedure for breaking down organic macromolecules into smaller fragments amenable to gas chromatography (GC) and is frequently used to help characterise geo- and biomacromolecules [1]. It is selective, however, to the thermally labile organic fraction. Constituents highly susceptible to thermal energy can dissociate to a basic elemental level whilst intractable macromolecular moieties may be resistant to even the high thermal energies applied during flash pyrolysis which typically involves ballistic heating to $>500^{\circ} \mathrm{C}$. Structurally significant hydrocarbon products within the $m / z, 20$ - 1000 detection range typically targeted by GC analysis may also include many unresolvable polar constituents. This can be particularly problematic for the characterisation of biochemicals in extant or immature OM. Nevertheless, the hydrocarbon products of mature samples such as kerogen appear to provide compositional information about gross structure and not about atypical, readily volatised apolar moieties [2].

The application of mild thermal regimes can provide greater control over the fragmentation process. The innovative approaches of MicroScale Sealed Vessel pyrolysis (MSSVpy) and catalysed hydropyrolysis (Hypy) have generated high pyrolysate yields from many organic materials spanning a broad range of thermal maturities. MSSVpy is conducted in the closed environment of a sealed tube for extended periods of up to several days at static temperatures in the moderate range of $250-350^{\circ} \mathrm{C}$. The pyrolysates are constrained within the tube until it is cracked, typically in a purpose built GC injector port, allowing on-line GC analysis [3] over the $C_{1}-C_{35}$ hydrocarbon range.

Hydropyrolysis is conducted from $300-550^{\circ} \mathrm{C}$ using much slower heating rates (e.g. $8^{\circ} \mathrm{C} / \mathrm{min}$ ) than the ballistic heating of flash pyrolysis. Metal sulphide catalysts can be used to reduce the thermal profile of volatile evolution, thus avoiding the application of very high temperatures which promote secondary cracking of primary aliphatic and aromatic pyrolysates [4,5]. Products are rapidly removed from the open-system thermal reactor, which is maintained under high hydrogen pressure (>10 MPa). These conditions 
support the relatively soft release of pyrolysis fragments, with minimal structural and isomeric rearrangement. The high pyrolysate yields obtained with catalyst assisted Hypy has previously been demonstrated by analysis of DCM-soluble oil detected from source rocks of different maturity [e.g. 4-7]. The off line nature of Hypy allows the total pyrolysate to be further manipulated by subsequent preparative procedures, such as liquid chromatography fractionation or chemical derivatisation, supporting compound specific detection.

Initial applications of MSSVpy and Hypy included studies of the character and formation kinetics of petroleum [3,8-13], but they have both also proved useful for structural characterisation of a broad range of organic materials, including extant biomass, dissolved organic carbon (DOC) and other sediments of low diagenetic alteration or thermal maturity [14-17]. The thermal control of both pyrolysis methods can facilitate access to structural constituents which have historically proved difficult to detect by analytical pyrolysis or other traditional analytical methods. Novel products have included the polyhydroxylated biohopanepolyol constituents of lipid membranes of prokaryotic bacteria [17-20]; hydrocarbon biomarkers from very early oil charges trapped and preserved within the asphaltene fraction of heavily biodegraded or otherwise altered oils [21-22]; the N-structural components of recent and extant OM [14-16] and the cleavage and reductive removal of other heteroatomic bonds, including ether, carboxyl, hydroxyl, sulfide, thiols, and simple thiophenic groups [7,20,23-27].

Here, the relative merits of MSSVpy and Hypy are compared. A small sample suite spanning a range of thermal maturities was analysed by each pyrolysis method. Separate flash pyrolysis analyses were conducted for comparison with a traditional data set. The bacteriohopanepolyol (BHP) structural constituents and precursors of the hopane pyrolysates of $\mathrm{F}$. aurantia and the biofoulant were targetted by LC-MS to extend the analytical correlation. Intact BHPs have been directly detected from bacterial isolates and sedimentary OM by LC-MS [29-33]. 


\section{Experimental}

\subsection{Samples}

\subsubsection{Frateuria aurantia}

The hopanoid containing acetic-acid bacterium Frateuria aurantia DSM $6220^{\mathrm{T}}(\mathrm{DSM}=$ German National Culture Collection, Braunschweig, Germany) was cultured as previously described [17]. Harvested cells were freeze dried into a pellet containing 9.86 x $10^{9}$ cells (mg dry wt) ${ }^{-1}$.

\subsubsection{Membrane biofoulant}

Insoluble biofoulant (BF) was obtained from the membrane filters of a drinking water treatment plant. Membrane sheets were obtained from spiral-wound modules taken at different stages of a high-pressure membrane filtration unit. The biomass fouling the pores of the membrane were physically removed, sonicated in MQ water and centrifuged to separate the soluble and insoluble fractions [34].

\subsubsection{Asphaltenes}

Asphaltenes were isolated from a West African oil seep [13]. Severe sub-surface biodegradation had removed all free hydrocarbons from the oil. The asphaltenes were precipitated from the remaining oil when dissolved in excess $n$-pentane.

\subsubsection{Kimmeridge Clay}

A sample of the Kimmeridge Clay Formation (KCF), a Type II marine source rock of Upper Jurassic age was collected from the beach at Blackstone Bay (2 km east of Kimmeridge Bay) Dorset UK. The sample (TOC $=26 \%$, HI = 597; S = 4.7 \%), was crushed and sieved to a particle size of $180-425 \mu \mathrm{m}$.

\subsection{Analysis}

\subsubsection{MSSV Pyrolysis GC-MS}

A previously described MSSVpy procedure was followed [17]. Small amounts of sample $(<0.1-2 \mathrm{mg})$ were loaded into $5 \mathrm{~cm}$ long x $5 \mathrm{~mm}$ i.d. glass tubes. Glass beads were added 
to fill the void volume and the tubes were flame sealed. The sealed tubes were heated isothermally for 72 hours at $300^{\circ} \mathrm{C}$ and then cracked inside a purpose built GC injector held at $300^{\circ} \mathrm{C}$. The asphaltene sample was separately heated at the higher temperatures of 330 and $360^{\circ} \mathrm{C}(72 \mathrm{hrs})$, since hydrocarbon generation from asphaltenes has been shown to be sensitive to temperatures in this range [21]. Helium carrier gas was used with a split of between $20-60 \mathrm{~mL} / \mathrm{min}$. Pyrolysates were cryogenically trapped at the start of the GC column with liquid nitrogen for 1 minute prior to GC-MS analysis with one of the two following instruments: 1) a Hewlett Packard (HP) 5890 Series II GC interfaced to an Autospec (UltimaQ) double-focusing mass spectrometer; 2) an Agilent 6890 GC interfaced to an Agilent 5973 mass selective detector (MSD). Both instruments used a $30 \mathrm{~m} \times 0.25 \mathrm{~mm}$ i.d. $\times 1 \mu \mathrm{m}$ film ZB5-MS column and the same GC oven programme of an initial $40^{\circ} \mathrm{C}$ (2 min isothermal) increased at $4^{\circ} \mathrm{C} / \mathrm{min}$ to a final $310^{\circ} \mathrm{C}(15 \mathrm{~min}$ isothermal $)$. Full scan analyses were performed from $m / z$ 50-550 with an electron energy of $70 \mathrm{eV}$. Tentative peak identifications were based on retention times and library and published mass spectra.

\subsubsection{Hydropyrolysis and product recovery for GC-MS:}

The apparatus and procedure for fixed bed catalytic Hypy has been described in detail elsewhere $[7,22,35]$. Samples were mixed with a dispersed sulphided molybdenum catalyst $\left[\left(\mathrm{NH}_{4}\right)_{2} \mathrm{MoO}_{2} \mathrm{~S}_{2}, 10 \mathrm{mg}\right.$, dissolved in a minimum of $20 \%$ methanol in water], dried gently and then transferred into the pyrolysis reactor. The catalyst-loaded samples (38 mg F. aurantia, $30 \mathrm{mg} \mathrm{BF}$ ) were then heated in a stainless steel reactor tube from ambient temperature to $250^{\circ} \mathrm{C}$ at $300^{\circ} \mathrm{C} \mathrm{min}^{-1}$, then to $500^{\circ} \mathrm{C}$ at $8^{\circ} \mathrm{C} \mathrm{min}^{-1}$. A constant hydrogen flow of $5 \mathrm{~L} \mathrm{~min}^{-1}$, measured at ambient temperature and pressure, ensured rapid removal-of the volatile products from the reactor vessel. The products were collected in a silica gel-filled trap cooled by dry ice.

The silica gel adsorbed hydropyrolysate was separated into aliphatic, aromatic and polar fractions by column chromatography with successive elution of $n$-pentane, dichloromethane in $n$-pentane $(30 \% \mathrm{v} / \mathrm{v})$ and dichloromethane in methanol $(50 \% \mathrm{v} / \mathrm{v})$, respectively. The aliphatic and aromatic fractions were analysed by GCMS. The same 
Agilent instrument used for the MSSVpy experiments was used for the biofoulant and isolate fractions. The asphaltene and Kimmeridge clay fractions were analysed with a Varian CP-3800 gas chromatograph, interfaced to a 1200 mass spectrometer (EI mode, $70 \mathrm{eV}, \mathrm{m} / \mathrm{z} 50$ - 550). Separation was achieved on a VF-1MS fused silica capillary column (50 $\mathrm{m}$ x $0.25 \mathrm{~mm}$ i.d., $0.25 \mu \mathrm{m}$ thickness), with helium as the carrier gas, and an oven programme of $50^{\circ} \mathrm{C}$ (hold for $2 \mathrm{~min}$ ) to $300^{\circ} \mathrm{C}$ (hold for $20.5 \mathrm{~min}$ ) at $4{ }^{\circ} \mathrm{C} \mathrm{min}^{-1}$.

\subsubsection{Flash pyrolysis $G C-M S$}

Flash pyrolysis $\left(0.5-1 \mathrm{mg}\right.$ sample) was performed at $\sim 550^{\circ} \mathrm{C}$ for 10 seconds using a Chemical Data Systems 160 pyroprobe and with the pyrolysis chamber at $250^{\circ} \mathrm{C}$. A HP 5890 Series II GC coupled to a 5971 mass selective detector (MSD) was used for pyrolysate detection. A $30 \mathrm{~m}$ x $0.25 \mathrm{~mm}$ i.d. x $1 \mu \mathrm{m}$ film ZB-5MS GC column was used with helium carrier gas ( 9 psi) with a split of between $20-50 \mathrm{~mL} / \mathrm{min}$. The GC temperature program was $40^{\circ} \mathrm{C}(2 \mathrm{mins})$ heated at $4^{\circ} \mathrm{C}$ to $310^{\circ} \mathrm{C}(15 \mathrm{mins})$. Full scan $\mathrm{m} / z$ $50-550$ mass spectra with an electron energy of $70 \mathrm{eV}$ and a transfer line of $310^{\circ} \mathrm{C}$.

\subsubsection{Lipid extraction and Liquid Chromatography Mass Spectrometry:}

Freeze-dried samples of $F$. aurantia $(50 \mathrm{mg})$ and the biofilm $(57 \mathrm{mg})$ were ground and extracted using a modified Bligh and Dyer method with Water/methanol/chloroform (19 $\mathrm{mL}, 4: 10: 5 \mathrm{v} / \mathrm{v}$ ) via a previously outlined procedure [33]. The extract was $\mathrm{N}_{2}$ dried, acetylated with acetic anhydride-pyridine $\left(4 \mathrm{~mL} ; 1: 1 \mathrm{v} / \mathrm{v} ; 50^{\circ} \mathrm{C}, 1 \mathrm{~h}\right), \mathrm{N}_{2}$ dried and dissolved in ca. methanol/2-propanol ( $1 \mathrm{~mL} ; 60 / 40 \mathrm{v} / \mathrm{v})$.

Reverse-phase HPLC analysis was carried out using a Surveyor HPLC system (Thermofinnigan, Hemel Hempstead, UK) fitted with a Gemini (Phenomenex) $\mathrm{C}_{18} 5 \mu \mathrm{m}$ column (150 mm x $3 \mathrm{~mm}$ i.d.) and a pre-column of the same material [32]. Separation was performed at $30^{\circ} \mathrm{C}$ with a flow rate of $0.5 \mathrm{~mL} / \mathrm{min}$ and the gradient profile: $90 \%$ methanol and 10\% water (at start); 59\% methanol, 1\% water and 40\% 2-propanol (at 25 $\min$ ), then isocratic to $60 \mathrm{~min}$. 
LC-MS $^{\mathrm{n}}$ was performed using a ThermoFinnigan LCQ ion trap mass spectrometer equipped with an APCI source operated in positive ion mode as described previously [29]. Detection was achieved at an isolation width of $m / z 5.0$ and fragmentation with normalised collisional dissociation energy of $35 \%$ and an activation Q value (parameter determining the $m / z$ range of the observed fragment ions) of 0.15 . LC-MS ${ }^{\mathrm{n}}$ was carried out in data-dependent mode with three scan events: SCAN 1: $m / z$ 300-1300 $\left(\mathrm{MS}^{1}\right)$; SCAN 2: data-dependent $\mathrm{MS}^{2}$ spectrum of the major $\mathrm{MS}^{1}$ ions; SCAN 3: data-dependent $\mathrm{MS}^{3}$ spectrum of the major $\mathrm{MS}^{2}$ ions. Structures were assigned from $\mathrm{MS}^{\mathrm{n}}$ comparison with published spectra [29-33] or known compounds. 


\section{Results and discussion}

\subsection{Hopanoids biomarkers of the bacterial isolate and biofoulant}

Bacteria of different taxonomy give rise to a range of BHP structures differing in the nature and positioning of the functional groups on the alkyl side chain. Hopane biomarkers can be used to fingerprint hopanoid-producing bacterial populations in present and palaeo-environments. The catagenetic reduction of hopanoids to hopanes in the geological record represents a natural model of the controlled thermal alteration of organic structures [1]. This same structural transformation has been laboratory contrived by both MSSVpy [17] and Hypy [20].

Semi-quantitative BHP data was obtained by LCMS to assess the integrity of the hopane signatures detected by MSSV and hydropyrolysis. The major BHPs detected by LC-MS of $F$. aurantia and the biofoulant are listed in Table 1, along with their likely precursors. Four $\mathrm{C}_{35}$ BHPs (1,7-9; Table 1) were detected from $F$. aurantia, although it is also known to biosynthesise $\mathrm{C}_{30}$ hopanoids [36]. The bacterial community of the biofoulant showed a more complex hopanoid profile with at least 7 known BHPs (1-7) and two novel products $(\mathbf{1 0 , 1 1})$, tentatively assigned as bacteriohopanepentol and bacteriohopanehexol glucosamines on the basis of their $\mathrm{MS}^{2}$ data $[29,37]$.

MSSVpy $\left(300^{\circ} \mathrm{C} / 72 \mathrm{hr}\right)$ and Hypy GCMS analysis of $F$. aurantia (Figure 1) and the biofoulant (Figure 2) showed similar $\mathrm{C}_{27}-\mathrm{C}_{31}$ hopane distributions. The most abundant products are listed in Table 2. The MSSVpy analyses of $F$. aurantia has been reported previously [17]. The hopane pyrolysates of both methods can be attributed to the thermal conversion of the highly polar hydroxylated hopanoid precursors into de-functionalised and more GC-amenable saturated analogues. Hopanes were not evident from the MSSVpy analysis of the fresh (non-matured) samples, nor from flash pyrolysis GCMS of the biofoulant. Flash pyrolysis GCMS of F. aurantia did include low concentrations of several $\mathrm{C}_{27}-\mathrm{C}_{31}$ hopane and hopene products [17], likely derived from hydroxyl free unsaturated triterpene constituents of the bacterial isolate (diploptene, hop-17(21)-ene and fern-7-ene). 
The hopane pyrolysates are fragmentation products of the predominant $\mathrm{C}_{35}-17 \beta, 21 \beta$ (22R) homohopane based BHPs detected by LC-MS. The Hypy data does reflect considerably higher proportions of $\beta \beta$ stereochemistry $(\mathbf{1 1}, \mathbf{1 6}, \mathbf{2 1}, \mathbf{2 5}, \mathbf{2 8 , 3 2 , 3 5}$; Table 2) and higher molecular weight (MW) hopanes, demonstrating 'softer' pyrolytic release of BHP structural units and better preservation of the structural integrity of the alkyl sidechain. The ability of Hypy to maximize the yields of covalently bound alkane biomarkers including $\beta \beta$ hopanes without significantly affecting their stereochemistry was demonstrated at an early stage of development [6]. The Hypy data of both the isolate and biofoulant did include $\beta \alpha$ and $\alpha \beta$ isomers reflecting the occurrence of a small degree of molecular rearrangement.

The extended heating times and closed-nature of MSSVpy probably contributes to more extensive cracking of the alkyl side-chain (lower concentrations of $>C_{31}$ hopanes) and more pronounced isomeric rearrangement (higher concentrations of more thermodynamically stable $\beta \alpha$ and $\alpha \beta$ isomers ) of the weakened $\mathrm{C}-\mathrm{C}$ covalent bonds adjacent to hydroxyl groups in the hopanoid extended side-chain [38].

Clearly, neither Hypy or MSSVpy provide the same level of intact BHP speciation provided by LCMS, nevertheless, the respective hopane distributions still reflect the different biohopanoid content of $F$. aurantia and the biofoulant samples and may contribute to appropriate screening methods to establish bacterial input prior to more complex characterisation methods such as LC-MS or gene specific biological assays. The micro-scale quantities (i.e. $<1 \mathrm{mg}$ ) of sample required for MSSV pyrolysis ( $c f .>30$ mg for Hypy) may also represent an important advantages for the characterisation of samples which are difficult to isolate in large quantities (e.g. NOM, isolates, biofoulants, other biomass).

\subsection{Hydrocarbons re-generated from the asphaltene fraction of a biodegraded oil.}

Biodegradation of oils can alter or remove most major hydrocarbon classes, and residual components may provide very little useful geochemical information. The simulation of thermal maturation by MSSVpy [21] and Hypy [22] can be used to release hydrocarbon 
biomarkers from the immature asphaltene fraction of biodegraded oils. Hypy of asphaltenes (> $30 \mathrm{mg}$ ) has been measured to yield product conversions of $400-500 \mathrm{mg} / \mathrm{g}$ $\mathrm{C}[22,35]$, which is approximately half the conversions typically achieved with immature kerogens [6]. Product conversions from MSSVpy treatment of asphaltenes $(\sim 1 \mathrm{mg})$ have not previously been determined.

Total ion chromatograms showing the $n$-alkane distribution obtained from the MSSVpy $\left(360^{\circ} \mathrm{C} / 72 \mathrm{hr}\right.$ ) and Hypy analysis of the asphaltene fraction of Soldado oil in which severe sub-surface biodegradation had removed all free phase hydrocarbons are shown in Figures 3. The different MW and relative abundances evident in the $n$-alkane distributons reflects the respective advantages of each pyrolysis method. The $n$-alkanes detected with MSSVpy ranged from $\mathrm{C}_{2}$ to beyond $\mathrm{C}_{30}$, and showed a general decrease in abundance with MW. The on-line GC analysis supports the detection of the gaseous range $n$-alkanes. The $n$-alkanes detected by Hypy start at $\mathrm{C}_{11}$, consistent with the difficulty of trapping $<\mathrm{C}_{8}$ hydrocarbons products [35], and extend to beyond $\mathrm{C}_{35}$ with a broad unimodal distribution. The generally high abundances of the $\mathrm{C}_{16}-\mathrm{C}_{26} n$-alkanes suggests the original oil was a mid range condensate. The $>\mathrm{C}_{14}$ region of the Hypy data also showed more pronounced carbon number preferences. The greater preservation of high MW structural features by Hypy can again be attributed to the relatively soft nature of macromolecular cleavage associated with this method.

$\operatorname{MSSVpy}\left(300^{\circ} \mathrm{C} / 72 \mathrm{hr}\right)$ and Hypy analysis of the asphaltenes was also able to generate hopane and sterane biomarkers not evident in the biodegraded parent oil (Figure 4). Higher concentrations of these saturated polycyclic hydrocarbons were again evident from the Hypy analysis, with $\mathrm{C}_{31}-\mathrm{C}_{35}$ extended hopanes evident. The predominance of $\alpha \beta$-isomers is consistent with their predominance in the original oil. As expected, the hopane concentrations of asphaltenes (Fig. 4) are much lower than in bacterial pure or rich samples (e.g., Figs 1-2). MSSVpy detection of hopane and sterane biomarkers is best supported by more moderate thermal conditions $\left(300^{\circ} \mathrm{C} / 72 \mathrm{hr}\right)$ than those $\left(360^{\circ} \mathrm{C} / 72\right.$ hr) used to effectively regenerate the $n$-alkanes typical of peak oil generation, highlighting the flexibility provided by the temperature controlled pyrolyses. 


\subsection{Detection of alkylthiophenes from Kimmeridge Clay}

The $n$-alkanes were also abundant products from the MSSVpy $\left(\geq \mathrm{C}_{2}\right)$ and Hypy $\left(\geq \mathrm{C}_{8}\right)$ GCMS of the Kimmeridge sample (Figure 5). The lower MW region of these chromatograms comprised relatively high concentrations of S-containing products such as alkyl-thiophenes (aTs), benzothiophenes and dibenzothiophenes which are selectively highlighted by the summed chromatograms shown in Figure 6. High concentrations of these products are consistent with the high sulphur content of the Kimmeridge sample.

MSSVpy produced thiophene and $\mathrm{C}_{1}-\mathrm{C}_{8}$ aT's with a pronounced decrease in concentrations with increasing alkyl substitution. Hypy produced a similar distribution of $\mathrm{C}_{3}-\mathrm{C}_{5}$ aT's, but again missed the volatile lower MW products. A similar distribution of aT's were detected by corresponding flash pyrolysis but in lower concentrations. The GC detection of their structural precursors and other fragments may be restricted by the structural polarity of the $\mathrm{S}$ group and its susceptibility to secondary reaction and alteration during flash pyrolysis [39-41].

ATs are prominent constituents of immature sedimentary macromolecules and type III-S kerogens [24-27,42-45]. Similar $\mathrm{C}_{1}-\mathrm{C}_{4}$ aT distribution patterns (dominated by $\mathrm{C}_{2}$ aTs) have been detected by MSSV pyrolysis of NOM [16] and flash pyrolysates of immature sulfur rich coals [24-27,42], soil and aquatic humic substances [46,47]. They and other reduced organic S compounds (e.g. thiol, sulfide) have been reported to account for more than $50 \%$ of the $\mathrm{S}$ content of aquatic and soil humic substances [48].

The low MW aTs have not generally been associated with any specific precursor. The high concentrations of aTs detected by MSSV pyrolysis of L-cysteine [16] suggested that thermal alteration of sulfur-containing amino-acids may be one pathway to environmental occurrences. Marine [49] and terrestrial sedimentary occurrences [43] of these products may involve inter- and intramolecular interaction of inorganic sulfur (i.e. $\mathrm{H}_{2} \mathrm{~S}$, polysulfides) with functionalised lipids during early diagenesis. 
Alkyl benzothiophene $\left(\mathrm{aBT} ; \leq \mathrm{C}_{4}\right)$ and alkyl dibenzothiophene $\left(\mathrm{aDBT} ; \leq \mathrm{C}_{2}\right)$ data from MSSVpy and Hypy are compared in Figure 6b. In sedimentary environments, aTs are converted to aBT and then aDBT with increasing maturity [50]. The MSSVpy and Hypy data showed $\mathrm{BT}$ and $\mathrm{C}_{1}-\mathrm{C}_{4}$ aBTs in similarly high concentrations. Low concentrations of dibenzothiophenes were detected by MSSVpy and trace levels by Hypy (Figure 8c). The very low Hypy concentrations may reflect a lower contrived maturity than with MSSVpy.

The efficient MSSVpy and Hypy detection of S-pyrolysates may be analogous to the efficient detection of N-organics of aquatic NOM [14,15] and the release and reduction of a range of $\mathrm{O}$ - and $\mathrm{S}$ - heteroatomic groups (e.g., ether, carboxyl, hydroxyl, sulfide, thiols and simple thiophenic groups) from sedimentary OM [6,20,23,24-26], similarly demonstrated by hydrous pyrolysis [45]. The release of S-structural sub-units of biochemicals or immature sedimentary OM may be favoured by the soft fragmentation afforded by each of these pyrolysis approaches.

\subsection{Operational Attributes}

Both instruments are commercially available. The more simplistic MSSV system is the least expensive, assuming access to an existing oven for the maturation process. Hypy has recently entered the commercial market place with a competitive price compared to other analytical pyrolysis methods (e.g. Rock-Eval). With the exception of the large amounts of hydrogen consumed by Hypy, both pyrolysis devices use low cost consumables.

Practical aspects of both the instrumentation and application of the MSSVpy and Hypy procedures are relatively straightforward. The previously presented data sets reflect the respective advantages of analytical sensitivity, MW range, preservation of primary structural units and complementary analytical steps. A brief appraisal of these and several other key operational issues are summarised in Table 3. 


\subsection{Conclusions.}

The high concentrations of pyrolysates consistently obtained by low temperature, controlled MSSVpy or Hypy of complex organic materials can complement traditional characterisation techniques and contribute to a more holistic structural appraisal. These sensitive analytical procedures can facilitate the "soft" release of additional pyrolysates or the partial reduction of a variety of polar structural constituents, present in relatively high concentrations in extant or immature $\mathrm{OM}$, that are not amenable to chromatographic analysis following conventional fast pyrolysis. The thermal release of many new structural units not detectable by flash pyrolysis GC-MS, emphasises the complimentary nature of different pyrolysis approaches.

In general, the MSSVpy and Hypy procedures have not been widely practiced in organic characterization studies, particularly of immature OM, and still require further demonstrations for wider acceptance. Nevertheless, here we demonstrate several useful applications including 1) the ready detection of hopane biomarkers useful for establishing the presence of bacterial input prior to investment in more complex microbial characterisation methods (e.g., LCMS, gene specific biological assays); 2) the thermal release of hydrocarbons sequestered in the asphaltene fraction of oils, assisting the hydrocarbon reconstruction of biodegraded oils; 3) The sensitive detection of S-organic products of S-rich type II kerogen, emulating the high yields of $\mathrm{N}$ - and O-products detected from analysis of other samples with these methods.

MSSVpy and Hypy are versatile methods which could contribute to a large number of advanced organic characterisation applications. Whilst both are able to provide comparable qualitative characterisation of a broad range of complex organic materials. several small but important distinctions were also evident. For example, more detailed and informative biomarker signatures were generally detected by Hypy due to greater preservation of structural (including isomeric) integrity. The off-line nature of Hypy also supports additional treatments to prepare fractions of reduced complexity for further analyses. On the other hand, MSSVpy can be conducted on very small samples, over an order of magnitude less in quantity than Hypy, which is particularly advantageous when 
sample quantities are limited. The online GC analysis of the MSSVpy method also supports the detection of gaseous range products.

\section{Acknowledgements:}

LJB acknowledges Curtin University of Technology and the Cooperative Research Centre for Water Quality and Treatment (CRC-WQT) for Post-Graduate Scholarship support. The membrane biofoulant sample was provided by Prof Jean-Philippe Croue (Poitier Uni). CES and WM thank NERC for financial support (Ocean Margins LINK, grant numbers NER/T/S/2001/01153 \& NE/C507002/1). HT thanks the Science Research Infrastructure Fund (SRIF) from HEFCE for analytical infrastructure and Martin Cooke and Robert Gibson for analytical assistance. 


\section{References}

1. K.E. Peters, C.C. Walters, J.M. Moldowan, The Biomarker Guide-Biomarkers and Isotopes in Petroleum Exploration and Earth History, Cambridge University Press, Cambridge. 2009.

2. S.R. Larter, B. Horsfield, In M.H. Engel, S.A. Macko (Eds), Organic Geochemistry Plenum Press, New York, 1993, pp 271-287.

3. B. Horsfield, U. Disko, F. Leistner, Geologische Rundshau 78 (1989) 361.

4. C.E. Snape, C. Bolton, R.G. Dosch, H.P. Stephens, Energy Fuel 3 (1989) 421.

5. M.J. Roberts, C.E. Snape, S.C. Mitchell, In: C.E. Snape (Ed.), Geochemistry Characterisation and Conversion of Oil Shales, NATO ASI Series C, vol. C455. Kluwer, Dordrecht, 1995, pp. 277-295

6. C.E. Snape, C.J. Lafferty, G. Eglington, N. Robinson, R. Collier, International Journal of Energy Research 18 (1994) 233.

7. G.D. Love, C.E. Snape, A.D. Carr, R.C. Houghton, Org. Geochem. 23 (1995) 981.

8. H.J. Schenk, B. Horsfield, Geochim. Cosmochim. Acta 57 (1993) 623.

9. V. Diekmann, H.J. Schenk, B. Horsfield, D.H. Welte, Fuel 77 (1998) 23.

10. V. Diekmann, H.J. Schenk, B. Horsfield, J. Anal. Appl. Pyrol. 56 (2000) 33.

11. I.P. Murray, G.D. Love, C.E. Snape, N.J.L. Bailey, Org. Geochem. 29 (1998) 1487.

12. C.A. Russell, C.E. Snape, W. Meredith, G.D. Love, E. Clarke, B. Moffatt, Org. Geochem. 35 (2004) 1441.

13. W. Meredith, C.E. Snape, A.D. Carr, H.P. Nytoft, G.D. Love, Org. Geochem. 39 (2008) 1243.

14. B. Bennett, A. Lager, C.A Russell, G.D. Love, S.R. Larter, Org. Geochem. 35 (2004) 1427.

15. L.J. Berwick, P.F. Greenwood, R.I. Kagi, J-P. Croué, Org. Geochem. 38 (2007) 1073.

16. L.J. Berwick, Characterisation of aquatic natural organic matter by micro-scale sealed vessel pyrolysis. PhD Dissertation. Dept. of Applied Chemistry, Curtin University of Technology. 2009, 265 p.

17. P.F. Greenwood, J.A. Leenheer, C. McIntyre, L. Berwick, P. Franzmann, Org. Geochem. 37 (2006) 597.

18. A.N. Bishop, G.D. Love, A.D. McAulay, C.E. Snape, P. Farrimond, Org. Geochem. 29 (1998) 989.

19. P. Farrimond, G.D. Love, A.N. Bishop, H.E. Innes, D.F. Watson, C.E. Snape, Geochim. Cosmochim. Acta 67 (2003) 1383.

20. G.D. Love, S.A. Bowden, L.L. Jahnke, C.E. Snape, C.N. Campbell, J.G. Day, R.E. Summons, R.E., Org. Geochem. 36 (2005) 63. 
21. T.E. Ruble, P.F Greenwood, M. Lisk, M. Ahmed, Proceed., $14^{\text {th }}$ Int. Symp. Anal. Appl. Pyrol (Seville, Spain) 2000, p 53.

22. W. Meredith, C-G. Sun, C.E. Snape, M.A. Sephton, G.D. Love, Org. Geochem. 37 (2006) 1705.

23. G.D. Love, A. McAulay, C.E. Snape, A.N. Bishop, Energy Fuels 11 (1997) 522.

24. M.P. Koopmans, J.S. Sinninghe-Damste, M.D. Lewan, J.W. de Leeuw Org. Geochem. 23 (1995) 583.

25. M.P. Koopmans, J.W. de Leeuw, M.D. Lewan, Org. Geochem. 25 (1996) 391.

26. M.P. Koopmans, C. Reiss, J.W. de Leeuw, M.D. Lewan, Geochim. Cosmochim. Acta 61 (1997) 2397.

27. Koopmans, M.P., Carson, F.C., Lewan, M.D., Sinninghe-Damste, J.S., 1998. Org. Geochem. 29, 1395.

28. H.M. Talbot, D.F. Watson, J.C. Murrell, J.F. Carter, P. Farrimond, J. Chrom. A 921 (2001) 175.

29. H.M. Talbot, A.H. Squire, B.J. Keely, P. Farrimond, Rapid Commun. Mass Spectrom. 17 (2003) 728.

30. H.M. Talbot, R. Summons, L. Jahnke, P. Farrimond, Rapid Commun. Mass Spectrom. 17 (2003) 2788.

31. H.M.. Talbot, P. Farrimond, Org. Geochem. 38 (2007) 1212.

32. H.M. Talbot, M. Rohmer, P. Farrimond, Rapid Commun. Mass Spectrom. 21 (2007) 1613.

33. H.M. Talbot, R.E. Summons, L.L. Jahnke, C.S. Cockell, M. Rohmer, P. Farrimond, Org. Geochem. 39 (2008) 232.

34. J-P. Croué, L. Grasset, S. Bacle, V. Jacquemet, Proceed. American Water Works Memb. Tech. Conf. (Atlanta, US), 2003.

35. W. Meredith, C.A. Russel, C.E. Snape, D. Fabbri, C.H. Vane, G.D. Love, Org. Geochem. 35 (2004) 73.

36. C. Joyeux, S. Fouchard, P. Llopiz, S. Neunlist, Microb. Ecol. 47 (2004) 371.

37. M.J.L. Coolen, H.M. Talbot, B.A. Abbas, C. Ward, S. Schouten, J.K.Volkman, J.S. Sinninghe Damsté, Environ. Microbiol. 10 (2008) 1783.

38. M. Rohmer, P. Bouvier-Nave, G. Ourisson, 1984. J. Gen. Microbiol. 130 (1984) 1137.

39. C. Saiz-Jimenez, Env. Sci. Tech. 28 (1994) 1773.

40. J.C. del Rio, F.J. González Vila, F. Martin, T. Verdejo, Org. Geochem. 22 (1996) 885.

41. J. Templier, S. Derenne, J-P. Croué, C. Largeau, C. Org. Geochem. 36 (2005) 1418.

42. J.S. Sinninghe-Damsté, F.X.C. de las Heras, J.W. de Leeuw, J. Chrom. 607 (1992) 361. 
43. W.A. Hartgers, J.S. Sinninghe-Damsté, J.W. de Leeuw, Y. Ling, G.R. Dyrkacz, Energy Fuels 8 (1994) 1055.

44. S. Zhiguang, B.D. Batts, J.W. Smith, Org. Geochem. 29 (1998) 1469.

45. A. Putschew, C. Schaeffer-Reiss, P. Schaeffer, M.P. Koopmans, J.W. de Leeuw, M.D. Lewan, J.S. Sinninghe Damsté, J.R. Maxwell, Org. Geochem. 29 (1998) 1875.

46. C. Saiz-Jimenez, J.W. de Leeuw, J. Anal. Appl. Pyrol. 9 (1986) 99.

47. X.Q. Lu , J.V. Hanna, W.D. Johnson, W.D. Chem. Geol. 177 (2001) 249.

48. K. Xia, F. Weesner, W.F. Bleam, P.R. Bloom, U.L. Skyllberg, P.A. Helmke, 62 (1998) 1246.

49. A.P. Deshmukh, B. Chefetz, P.G. Hatcher, Chemosphere 45 (2001) 1007.

50. J.C. Schmid, J. Connan, P. Albrecht, Nature 329 (1987) 54. 


\section{Table Captions}

Table 1. Structure, relative abundance (\%) and known sources of intact bacteriohopanepolyols from the LCMS of $F$. aurantia and the biofoulant.

Table 2. Hopane products from MSSVpy and Hypy analysis of F. aurantia, biofoulant and asphaltene samples.

Table 3. Operational attributes of MSSVpy and Hypy. The relative merits of several attributes are qualitatively indicated by $4 *$ rating system: * $*_{* * *}$ reflects low - high merit.

\section{Figure Captions}

Figure 1. Partial $\mathrm{m} / \mathrm{z} 191$ chromatogram showing the distributions of hopanes detected from $F$. aurantia by a) $300^{\circ} \mathrm{C} / 72 \mathrm{hr}$ MSSVpy GC-MS; and b) Hypy GC-MS. Hopane assignments are listed in Table 2.

Figure 2. Partial $\mathrm{m} / \mathrm{z} 191$ chromatogram showing the distributions of hopanes detected from the biofoulant by a) $300^{\circ} \mathrm{C} / 72 \mathrm{hr}$ MSSVpy GC-MS; and b) Hypy GC-MS. Hopane assignments are listed in Table 2.

Figure 3. Total ion chromatograms from analysis of the asphaltene fraction of Soldado oil by a) $360^{\circ} \mathrm{C} / 72 \mathrm{hr}$ MSSVpy and b) Hypy analysis.

Figure 4. Partial summed $\mathrm{m} / \mathrm{z} 191$ and 217 chromatogram showing the distributions of steranes and hopanes detected from the asphaltene by a) $300^{\circ} \mathrm{C} / 72 \mathrm{hr} \mathrm{MSSVpy}$ GC-MS; and b) Hypy GC-MS. Hopane assignments are listed in Table 2. $\mathrm{C}_{27} \mathrm{~S}$ / $\mathrm{C}_{29} \mathrm{~S}=$ steranes.

Figure 5. Total ion chromatograms from analysis of the Kimmeridge clay by a) $300^{\circ} \mathrm{C} / 72 \mathrm{hr}$ MSSVpy and b) Hypy (TIC of saturates fraction) analysis.

Figure 6. Selected ion chromatogram showing the distributions of a) alkyl thiophenes; b) alkyl benzothiophenes; and c) alkyl dibenzothiophenes detected by $300^{\circ} \mathrm{C} / 72 \mathrm{hr}$ MSSVpy GC-MS (left) and Hypy GC-MS (right). 
Table 1. Structure, relative abundance (\%) and known sources of intact bacteriohopanepolyols from the LCMS of $F$. aurantia and the biofoulant.

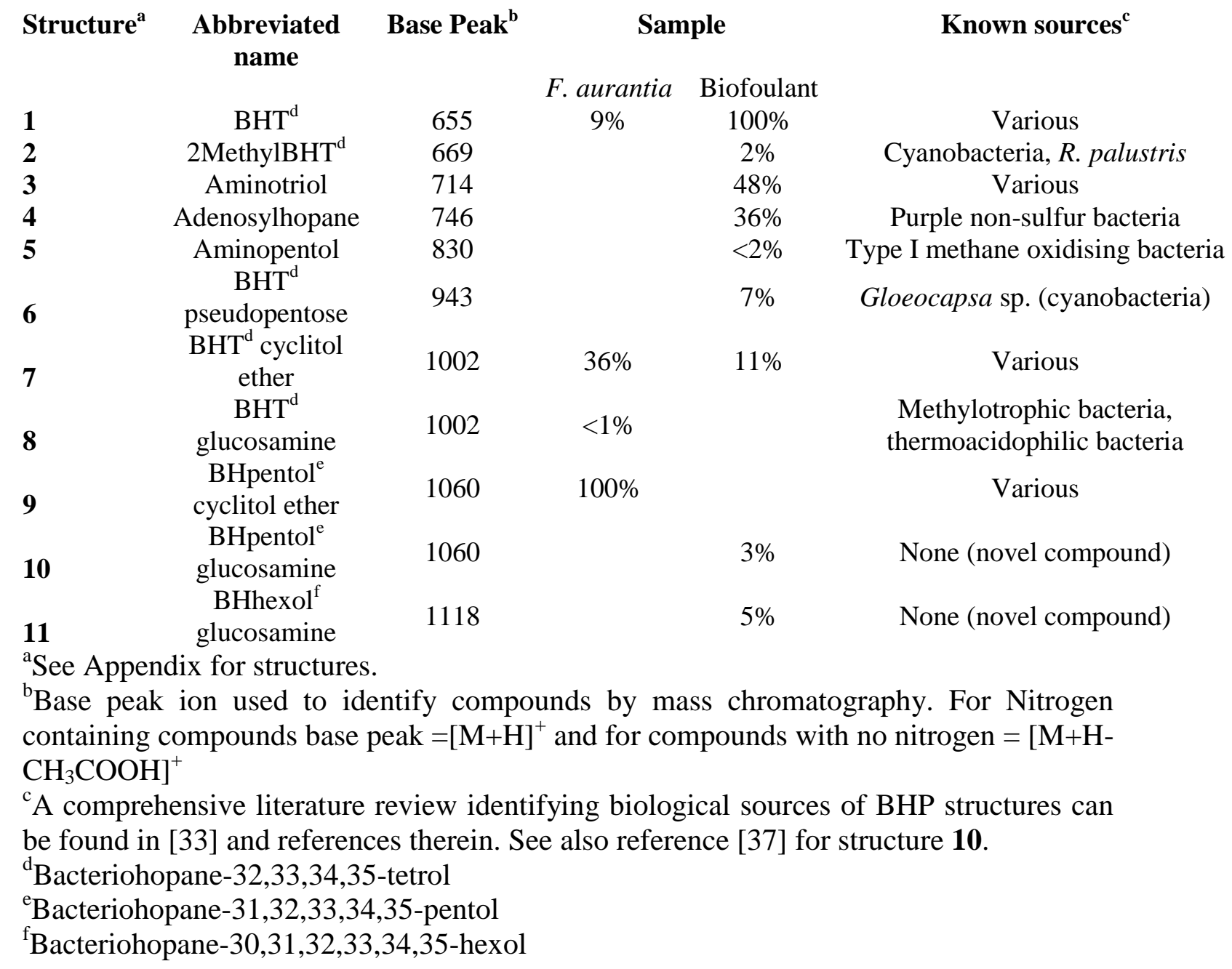


Table 2. Hopane products from MSSVpy and Hypy analysis of F. aurantia, biofoulant and asphaltene samples.

\begin{tabular}{|c|c|c|}
\hline Peak No. & Abbrev. & Compound \\
\hline 1 & $T_{s}$ & $18 a(H)-22,29,30$-trisnorhopane \\
\hline 2 & $\mathrm{C}_{27} \mathrm{H}:$ & Monounsaturated $\mathrm{C}_{27}$ hopene \\
\hline 3 & $\mathrm{~T}_{\mathrm{m}}$ & $17 \alpha(H)-22,29,30$-trisnorhopane \\
\hline 4 & $27 \beta$ & $17 \beta(H)-22,29,30$-trisnorhopane \\
\hline 5 & $\mathrm{C}_{29} \mathrm{H}:$ & Monounsaturated $\mathrm{C}_{29}$ hopene \\
\hline 6 & $\mathrm{C}_{29} \mathrm{H}$ & $17 \alpha, 21 \beta-30$-norhopane \\
\hline 7 & $\mathrm{C}_{29} \mathrm{H}:$ & Monounsaturated $\mathrm{C}_{29}$ hopene \\
\hline 8 & $\mathrm{C}_{30} \mathrm{H}:$ & Monounsaturated $\mathrm{C}_{30}$ hopene \\
\hline 9 & $\mathrm{C}_{29} \beta \alpha$ & $17 \beta, 21 \alpha-30$-normoretane \\
\hline 10 & $\mathrm{C}_{30} \mathrm{H}$ & $17 \alpha, 21 \beta$-hopane \\
\hline 11 & $\mathrm{C}_{29} \beta \beta$ & $17 \beta, 21 \beta$-30-norhopane \\
\hline 12 & $\mathrm{C}_{30} \beta a$ & $17 \beta, 21 \alpha$-moretane \\
\hline 13 & $\mathrm{C}_{30} \mathrm{H}:$ & Monounsaturated $\mathrm{C}_{30}$ hopene \\
\hline 14 & $\mathrm{C}_{31} \mathrm{H}(\mathrm{S})$ & $17 \alpha, 21 \beta$-30-homohopane (22S) \\
\hline 15 & $\mathrm{C}_{31} \mathrm{H}(\mathrm{R})$ & $17 \alpha, 21 \beta$-30-homohopane (22R) \\
\hline 16 & $\mathrm{C}_{30} \beta \beta$ & $17 \beta, 21 \beta$-hopane \\
\hline 17 & $\mathrm{C}_{31} \beta a(\mathrm{R})$ & $\mathrm{C}_{31} 17 \beta, 21 \alpha$-hopane (22R) \\
\hline 18 & $\mathrm{C}_{32} \mathrm{H}(\mathrm{S})$ & $\mathrm{C}_{32} 17 \alpha, 21 \beta$-hopane (22S) \\
\hline 19 & $\mathrm{C}_{32} \mathrm{H}(\mathrm{R})$ & $\mathrm{C}_{32} 17 \alpha, 21 \beta$-hopane (22R) \\
\hline 20 & $\mathrm{C}_{32} \beta a(\mathrm{R})$ & $\mathrm{C}_{32} 17 \beta, 21 \alpha$-hopane (22R) \\
\hline 21 & $\mathrm{C}_{31} \beta \beta$ & $17 \beta, 21 \beta$-30-homohopane \\
\hline 22 & $\mathrm{C}_{33} \mathrm{H}(\mathrm{S})$ & $\mathrm{C}_{33} 17 \alpha, 21 \beta$-hopane (22S) \\
\hline 23 & $\mathrm{C}_{33} \mathrm{H}(\mathrm{R})$ & $\mathrm{C}_{33} 17 \alpha, 21 \beta$-hopane (22R) \\
\hline 24 & $\mathrm{C}_{33} \beta a(\mathrm{R})$ & $\mathrm{C}_{33} 17 \beta, 21 \alpha$-hopane $(22 \mathrm{R})$ \\
\hline 25 & $\mathrm{C}_{32} \beta \beta$ & $\mathrm{C}_{32} 17 \beta, 21 \beta$-hopane \\
\hline 26 & $\mathrm{C}_{34} \mathrm{H}(\mathrm{S})$ & $\mathrm{C}_{34} 17 \alpha, 21 \beta$-hopane (22S) \\
\hline 27 & $\mathrm{C}_{34} \mathrm{H}(\mathrm{R})$ & $\mathrm{C}_{34} 17 \alpha, 21 \beta$-hopane (22R) \\
\hline 28 & $\mathrm{C}_{33} \beta \beta$ & $\mathrm{C}_{33} 17 \beta, 21 \beta$-hopane \\
\hline 29 & $\mathrm{C}_{35} \mathrm{H}(\mathrm{S})$ & $\mathrm{C}_{35} 17 \alpha, 21 \beta$-hopane (22S) \\
\hline 30 & $\mathrm{C}_{35} \mathrm{H}(\mathrm{R})$ & $\mathrm{C}_{35} 17 \alpha, 21 \beta$-hopane (22R) \\
\hline 31 & $\mathrm{C}_{35} \beta a(\mathrm{R})$ & $\mathrm{C}_{35} 17 \beta, 21 \alpha$-hopane (22R) \\
\hline 32 & $\mathrm{C}_{34} \beta \beta$ & $\mathrm{C}_{34} 17 \beta, 21 \beta$-hopane \\
\hline 33 & $\mathrm{C}_{35} \mathrm{H}:$ & Monounsaturated $\mathrm{C}_{35}$ hopene \\
\hline 34 & $\mathrm{C}_{35} \mathrm{H}:$ & Monounsaturated $\mathrm{C}_{35}$ hopene \\
\hline 35 & $\mathrm{C}_{35} \beta \beta$ & $\mathrm{C}_{35} 17 \beta, 21 \beta$-hopane \\
\hline 36 & $\mathrm{C}_{35} \mathrm{H}:$ & Monounsaturated $\mathrm{C}_{35}$ hopene \\
\hline
\end{tabular}


Table 3. Operational attributes of MSSVpy and Hypy. The relative merits of several attributes are qualitatively indicated by $4 *$ rating system: * $*_{* * *}$ reflects low - high merit.

\begin{tabular}{|c|c|c|}
\hline Attribute & MSSVpy & Нypy \\
\hline $\begin{array}{l}\text { Cost - ca. } \\
\text { dependent on } \\
\text { configuration } \\
\text { (Cf. Rock Eval } \\
\sim \text { US\$80K) }\end{array}$ & $\begin{array}{l}\qquad * * * \\
<\mathrm{US} \$ 30 \mathrm{~K} \\
\text { GC injector and accessories }\end{array}$ & $\begin{array}{l}\qquad * * * \\
>\mathrm{US} \$ 60 \mathrm{~K} \\
\text { High pressure } \mathrm{H}_{2} \text { vessel and } \\
\text { accessories }\end{array}$ \\
\hline $\begin{array}{l}\text { Sensitivity - } \\
\text { Sample quantity } \\
\text { (typical) }\end{array}$ & $0.1-2.0 \mathrm{mg}$ & $>30 \mathrm{mg}$ \\
\hline Ease of Use & $\begin{array}{l}\qquad * * * * \\
\text { Off-line maturation/online GCMS } \\
\text { analysis }\end{array}$ & $\begin{array}{l}\qquad * * * \\
\text { Off-line maturation/solvent recovery } \\
\text { silica adsorbed } \\
\text { pyrolysates/fractionation/GCMS } \\
\text { High pressure } \mathrm{H}_{2} \text { safety issues }\end{array}$ \\
\hline MW range & $\begin{array}{l}\qquad * * * * \\
\text { Online GC analysis allows detection } \\
\text { of gaseous and low MW products }\end{array}$ & $\begin{array}{l}\qquad * * \\
\text { Solvent recovery misses gaseous } \\
\text { range }\end{array}$ \\
\hline $\begin{array}{l}\text { Preservation of } \\
\text { primary structural } \\
\text { Units }\end{array}$ & $\begin{array}{c}\qquad * * \\
\text { More product alteration than Hypy }\end{array}$ & $\begin{array}{l}\qquad * * * \\
\text { Less product alteration than MSSV }\end{array}$ \\
\hline $\begin{array}{l}\text { Complimentary } \\
\text { Product Analysis }\end{array}$ & $\begin{array}{l}\qquad * * \\
\text { Online GC analysis limits } \\
\text { subsequent fractionation or } \\
\text { derivatisation }\end{array}$ & $\begin{array}{l}\qquad * * * * \\
\text { Column chromatography and other } \\
\text { fractionation procedures can be used }\end{array}$ \\
\hline
\end{tabular}


Appendix. Bacteriohopanepolyol structures (cf. Table 1). The steochemistry indicated was previously determined by NMR studies, however, other stereochemistries may be possible.

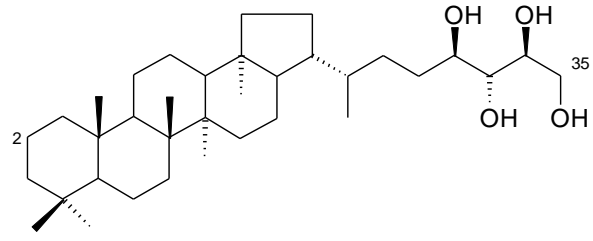

1

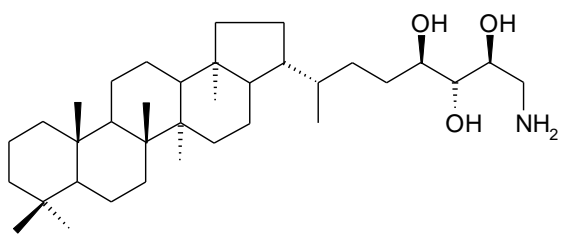

3

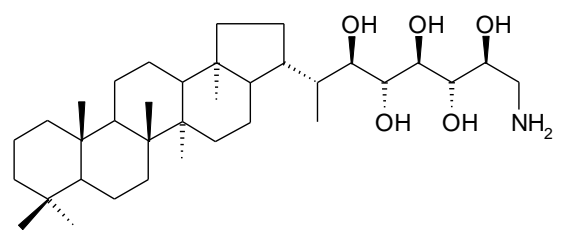

5<smiles>CC(CCC(O)CC(O)COC1C(N)C(O)C(O)C1(C)CO)[C@H]1CCC2C1CC[C@@]1(C)C2CCC2C1CCC1CCCC[C@]12C</smiles>

7

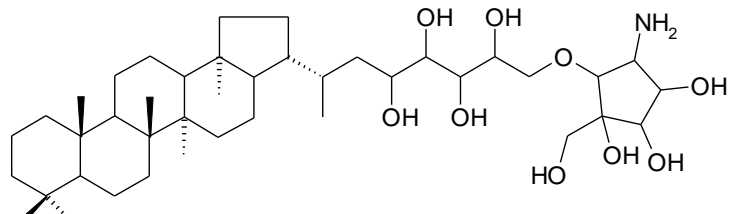

9<smiles>CC(C(O)C(O)C(O)C(O)C(O)COC1OC(CO)C(O)C(O)C1N)C1CCC2C1CCC1C2CCC2C(C)(C)CCCC12C</smiles>

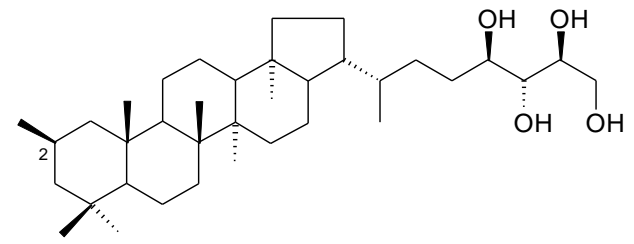

2

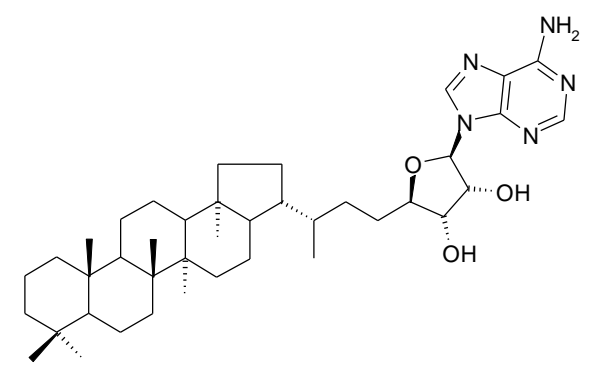

4

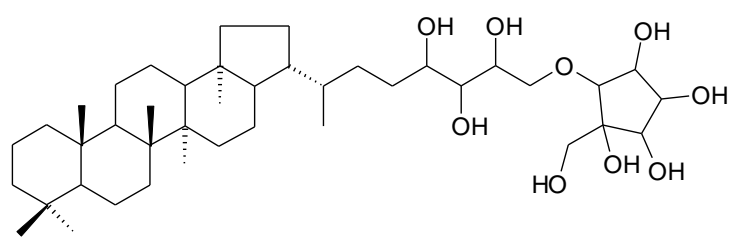

6



8<smiles>CC(CC(O)C(O)C(O)C(O)COC1OC(CO)C(O)C(O)C1N)C1CCC2C1CCC1C2CCC2C1CCC1C2(C)CCC2C(C)(C)CCCC21C</smiles>

10

11 







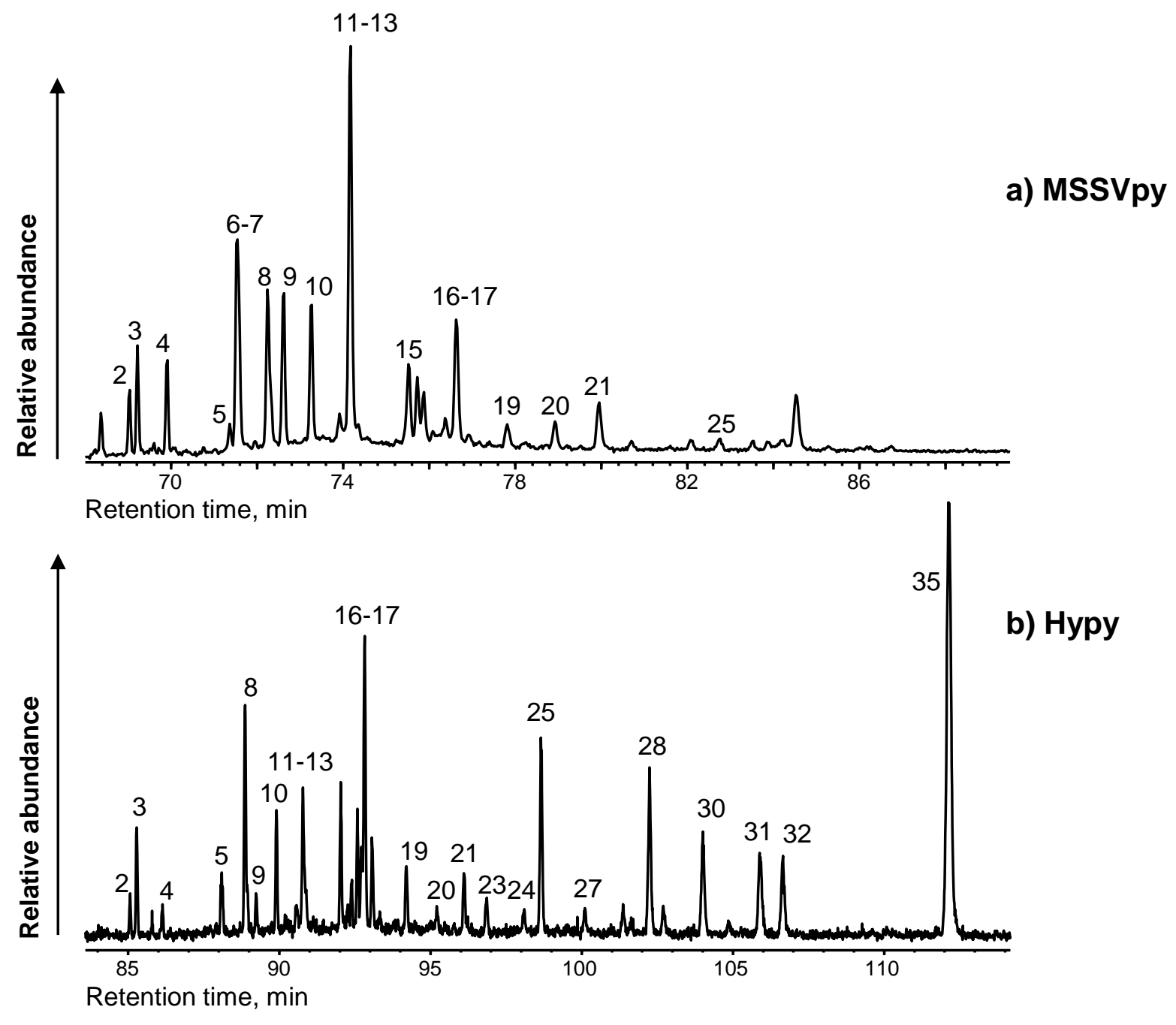



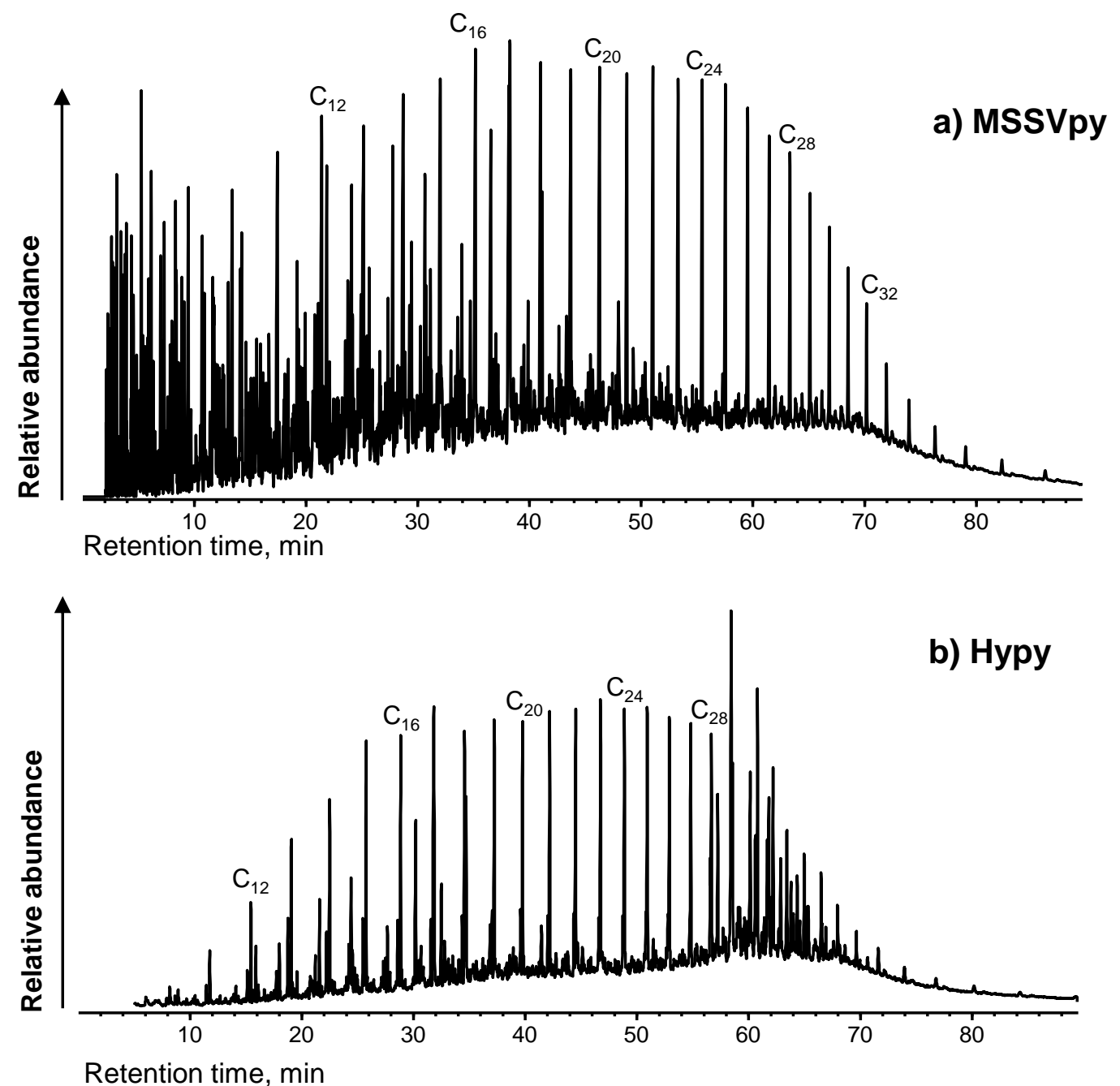


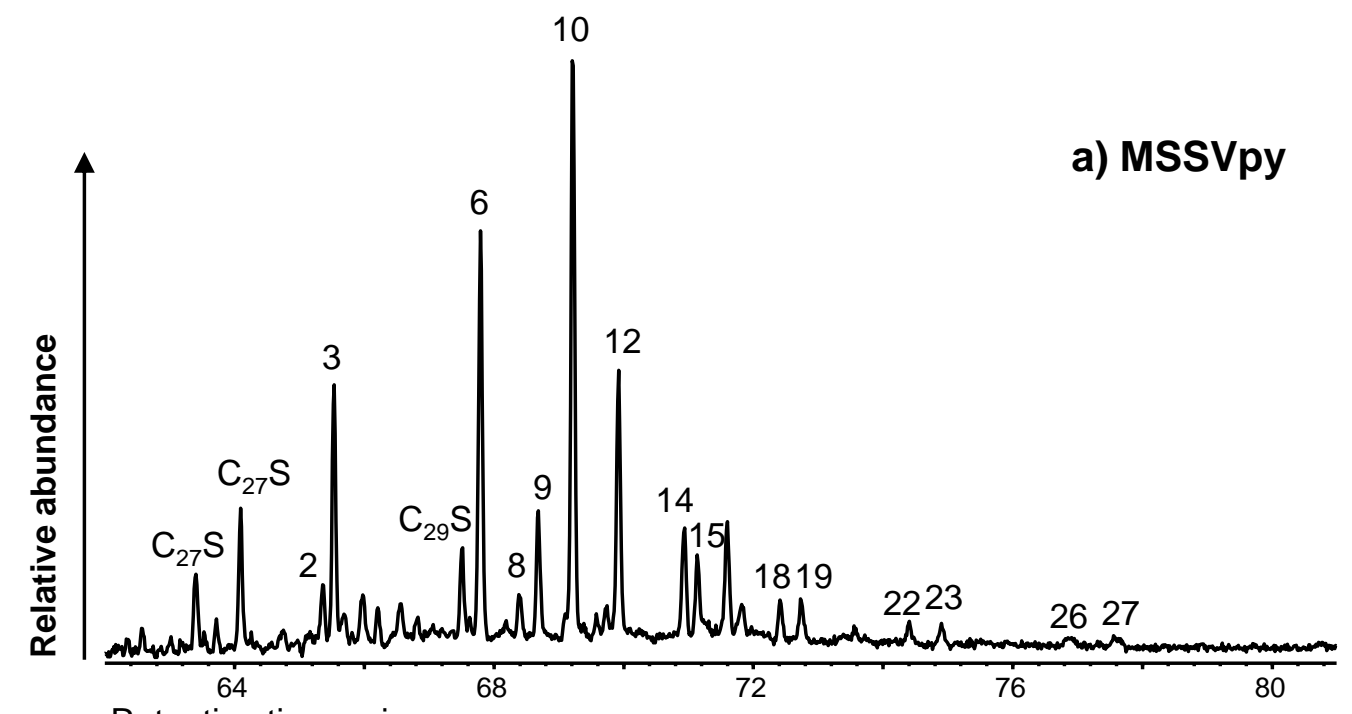

Retention time, min

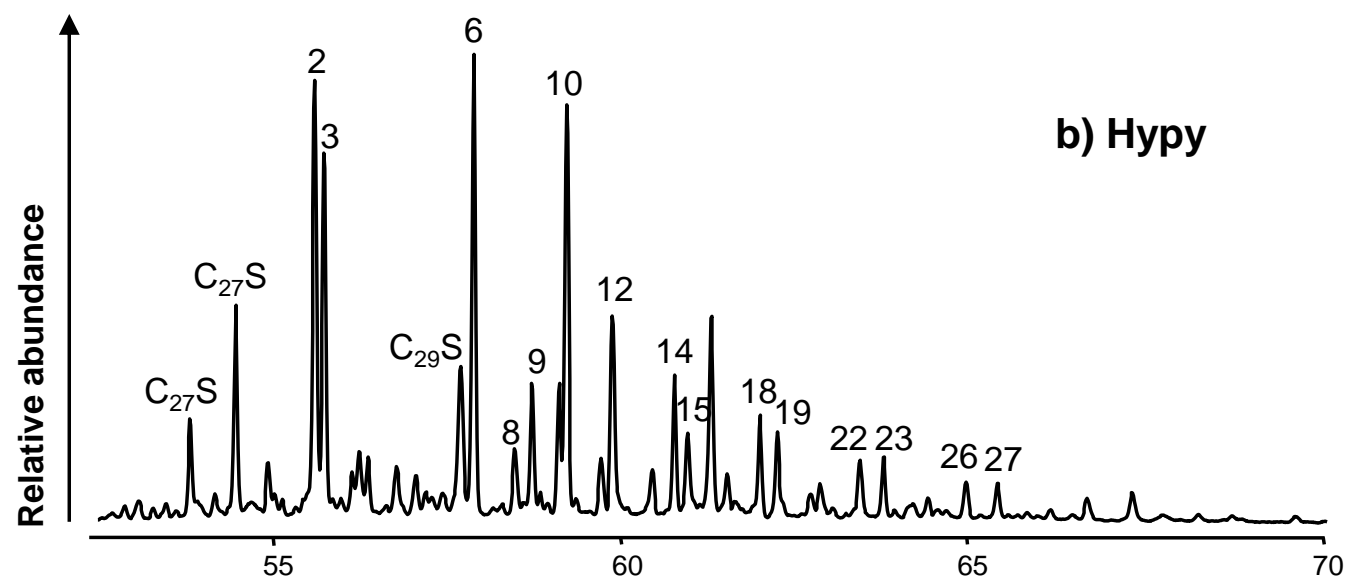

Retention time, $\min$ 

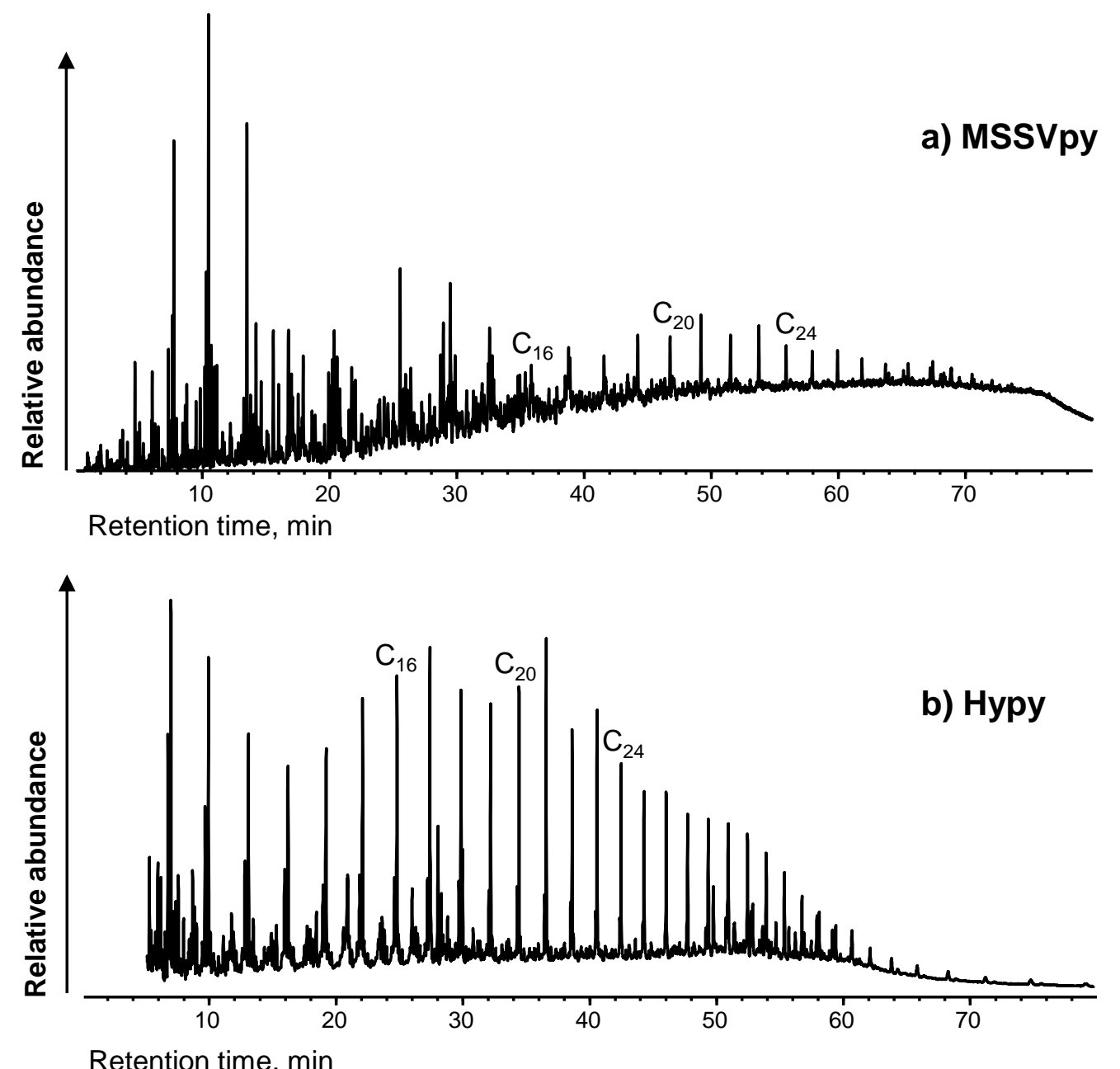

Retention time, min 

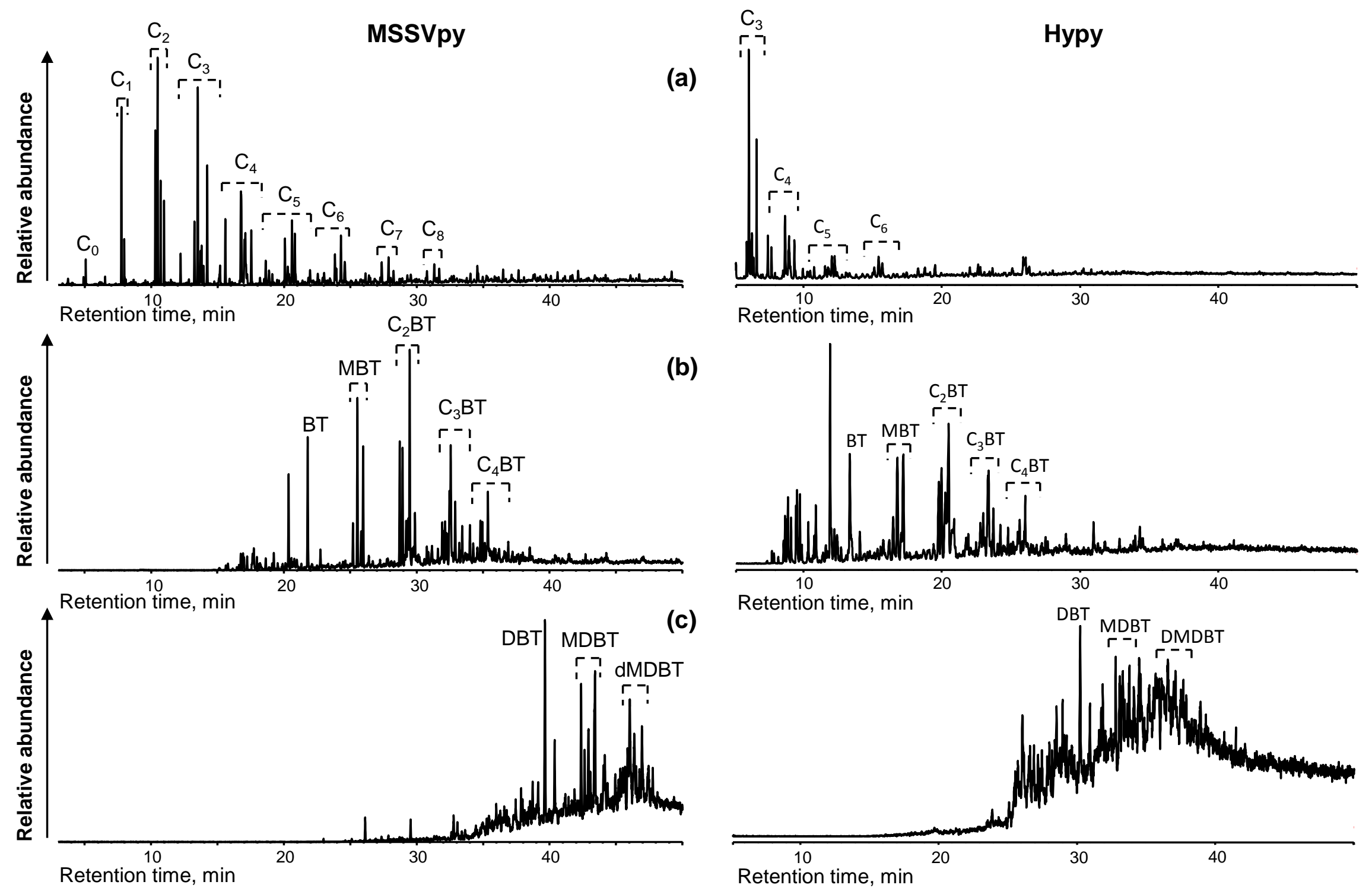

Retention time, min 